\title{
EVALUATION OF THE STATEMENT OF TATIANA MASLOVSKAYA ABOUT THE NEW TRENDS IN ELECTORAL LAW IN THE CIS COUNTRIES IN THE PERIOD FROM 2017 TILL 2019

\author{
Ekaterina Marmilova $^{1}$
}

\begin{abstract}
During the period from 2017 till 2019, there is a tendency of acceptance of new norms in Electoral Codes and Constitutional laws in the CIS countries. The author analyzed the hypothesis by Tatiana Maslovskaya about the evolution of electoral legislation in the CIS countries and new trends as codification, globalization, democratization in electoral law, by making the analysis of the amendments to the Electoral Codes and Constitutional Laws of the CIS countries in the period from 2017 to 2019. The globalization trend of electoral legislation in the CIS countries was not clearly expressed in those amendments, additions that were adopted in the research period.

Conclusions: There is a tendency for individual CIS countries to codify their electoral legislation in codification format since they haven't done it before. The democratization trend is clearly expressed in the amendments.
\end{abstract}

UDC Classification: 324, DOI: https://doi.org/10.12955/pss.v2.230

Keywords: Electoral Code, The CIS countries, state member of the CIS countries, electoral standards electoral law

\section{Introduction}

Presently the presence of an electoral code becomes the obligatory attribute of any state. A situation with Electoral Codes in the CIS countries is especially actual because some countries of the CIS countries already so much time use a Code for systematization of the electoral legislation: the Republic of Azerbaijan, Republic of Belarus, Republic of Moldova, and Republic of Armenia. In other countries of the CIS countries, instead of Electoral Codes, they use the constitutional laws: the Republic of Kazakhstan, Republic of Tajikistan, and Republic of Kirghizia. Russian Federation made a decision about the development and acceptance of the Electoral Code in July 2018. In the research period from the 2017 till 2019, substantial amendments and supplements were brought in Electoral Codes and the Constitutional laws of CIS.

\section{Literature review}

The scientists have not yet considered new changes and additions to the Election Codes and Constitutional laws of the CIS countries in the research period from 2017 till the 2019. Alekhina examines the electoral standards of CIS, set by the Convention about the standards of democratic elections, the right to vote, and freedoms in the states-participants of the CIS countries (Alekhina, 2016). Borukhina has studied electoral systems in the EU and the CIS countries. She concluded that the presence of many forms of electoral systems confirms the absence of their ideal model and the multidimensional of their nature (Borukhina, 2013). According to Potapova, "The electoral codes of the Republic of Azerbaijan, the Republic of Moldova, the Republic of Belarus contain all the basic norms of the electoral law and regulate the electoral process in a systematic way detail" (Potapova, 2014). According to Casanovskaya and Ganitsky, one of the directions of constitutional reform in the CIS countries in the coming years may be the improvement of the rules governing the foundations of the electoral system, based on experience" (Casanovskaya and Ganitsky, 2016).

\section{Data and methodology}

Methods of the scientific research: the analysis of the amendments to the Electoral Codes and Constitutional Laws of the CIS countries in the period from 2017 to 2019.

\section{Analysis}

The main aim of this article is to analyse the statement by T. Maslovskaya about the evolution of electoral legislation in the CIS countries and new trends as codification, globalization, and democratization in electoral law by making the analysis of the amendments to the Electoral Codes and Constitutional Laws of the CIS countries in the period from 2017 to 2019. T. Maslovskaya educed the tendencies of evolution the electoral legislation in CIS: the tendency of systematization of electoral legislation as codification, the tendency of globalization, expressed in a reflection in the electoral legislation of the CIS countries international electoral standards, the tendency of democratization that

\footnotetext{
${ }^{1}$ Higher School of Economics, Perm, Russian Federation, marmilova.ekaterina@ mail.ru, http://orcid.org/00000001-5775-6018
} 
shows up in the expansion of guarantees of realization of rights for the participants of the electoral process (electors, observers, candidates on elective offices) (Maslovskaya, 2012).

We decided to analyze this hypothesis by monitoring the new changes made to the electoral law in the CIS countries.

In January 2018, 55 amendments were made to the Electoral Code of the Republic of Azerbaijan. Most of the amendments were related to bringing the norms of the Electoral Code of the Republic of Azerbaijan in line with the Constitution of the Republic of Azerbaijan. Other changes in the Electoral Code mainly carried technical character. According to article 175 of the Code, Central Election Committee made a decision about the privation of the deputy mandate (Sputnik Azerbaidzan, 2018).

The Parliament of the Republic of Belarus was brought in a suggestion about making additions to the Electoral Code. Basic changes were sent to the expansion of rights for observers on June 12 in 2019. The prepared amendments in the Electoral Code of the Republic of Belarus let the observers fix the voting process during the elections, including the process of the count of voices, to use any technical equipment, including the audio recording, photo- and video survey. Some amendments were touching the pre-schedule voting too (Avseyushkin, 2019).

Ukraine belongs to the founding countries of CIS. An application stopping Ukraine's participation in CIS has not been submitted. In this connection, Ukraine was invited to the Summit of CIS in October, 2019. In July, 2019, the Parliament of Ukraine had accepted the Electoral Code with plenty of changes and additions (4568). On the basis of new norms, in Ukrainian parliament will be doing the new election with opening party lists system with regional districts. One mandate district is replaced by regional districts. Every district party can make own list of candidates. The passage barrier will remain at 5\% (Kharchenko, 2019).

In June 2019, an Electoral Code was accepted in the Republic of Uzbekistan. The Electoral Code of the Republic of Uzbekistan contains new legal norms: about the possibility of making voting papers based on the alphabet of Braille, about percent correlation of the number of women and men from the incurrence of the candidates in deputies, pulled out from the political party, about the possibility of the citizen to declare in a district election committee about an error or inaccuracy in the registers of voters (Sputnik Azerbaidzan, 2019).

In September 10, 2019, the National Parliament of Armenia decided to begin the process of bringing amendments in the Electoral Code and in Electoral Law «About parties». The following norms will be changed by the parliament of Armenia: rating voting system, mechanisms of permission of electoral spores, duration of electoral companies, requirements to the candidate in deputies, transparency of sourcing of parties (Press Center Regnum, 2019).

In the Republic of Tajikistan, the members of political parties will not be able to enter the country's Central Election Committee. Changes were brought in on June 26, 2019, in a law «On the Central commission on elections and referendums of Republic of Tajikistan». The members of political parties of Tajikistan will be able to enter in the complement of circuitous election committees only if will stop the membership in rows of parties. Amendments will effective on the next parliamentary and presidential elections in 2020 (Press club in the Sughd region of the Republic of Tajikistan, 2019).

The Central Commission for the Conduct of Elections and Referenda in Turkmenistan said that in July, 27, 2017, in the Electoral code of Turkmenistan, some new legal changes were included. Circuitous Election Committees must form the Central Election Committee in the composition of 9-11 members, election committees of the city appear in composition 7-11 members». Political parties can pull out only one candidate in Presidents of Turkmenistan (Central Commission for the Conduct of Elections and Referenda in Turkmenistan, 2018)

The Constitutional law «On elections in the Republic of Kazakhstan» on May 23, 2018, were included some new legal changes. It entered the proportional system of elections of deputies in local representative organs and elections of heads of cities of district value, villages, settlements, and rural districts. A document also abolished circuitous Election Committees and translated the registers of voters in an electronic format (Press Center Regnum, 2018).

S. Jeenbekov confirmed that on August 13, 2019, the President of the Kyrgyz Republic signed a package of laws aimed at improving the electoral law: norms on the inadmissibility of abuse of administrative 
resources, measures to improve the inclusiveness (involvement) of citizens in the electoral process, norms on monitoring and transparency of election campaign financing (Jeenbekov, 2019).

The draft of the Electoral Code of the Russian Federation is presented on the website of the Russian Foundation for Free Elections (Russian Foundation for Free Elections, 2019). The general part includes legal provisions on the designation of elections and referendums, registration and registration of voters, referendum participants, principles for the formation of electoral districts, referendum districts, polling stations, referendum precincts, the procedure for the formation and powers of the election commission of the Russian Federation, election commissions of constituent entities of the Russian Federation, municipalities and others, provisions on electoral associations, on public control during elections and etc.

In April 2019, the Chairman of the Central Election Committee in the Republic of Moldova, Ivan Komur said, that «the before a year of elections in an electoral legislation must not be included the new changes, because these changes can influence a mistrust to the results of elections». In Moldova, there is a problem with the creation of the official Register of Electors (Central Election Commission of Gagauzia, 2019).

\section{Results}

Of particular importance is the formation of high-quality legislation on elections and referendums, their organization and conduct, as well as the recognition of voting results by participants in the electoral process and the international community.

Ukraine, the Republic of Uzbekistan, the Russian Federation are going to codify their electoral legislation.

The Republic of Kyrgyzstan, the Republic of Kazakhstan, and the Republic of Tajikistan use constitutional laws as a format for regulating election legislation.

There is a tendency for individual CIS countries to codify their electoral legislation in codification format since they haven't done it before.

About the globalization trend of electoral legislation in the CIS countries: we believe that this trend was not clearly expressed in those amendments, additions that were adopted in the research period from the 2017 to the 2019.

The democratization trend is clearly expressed in the amendments that were adopted in the Republic of Belarus.

\section{Conclusions}

Thus, the CIS countries do not examine the presence of the Electoral Code, as the only possible format of the legislative adjusting of election procedure. Presently there is a tendency of acceptance of new norms in Electoral Codes and Constitutional laws of the CIS countries in a research period from 2017 till 2019.

Amendments and additions concern the settlement of a huge number of issues of suffrage. The issues related to the foundations of the organization of the electoral system of the CIS countries are being reviewed. For example, the Republic of Kazakhstan switched to a proportional system of election of deputies, and in Ukraine, voting was introduced on open party lists.

The newly adopted Election Code of Uzbekistan in June 2019 includes provisions on the organization of voting, taking into account new global trends in public administration, for example, a provision on the percentage of women and men in the total number of candidates.

\section{References}

Alekhina, I.S. (2016) CIS election standards. Management Consulting. In. Politics and the rule of law, 9, 60-67. https://tinyurl.com/p5u2kef4

Avseyushkin Y. (2019, June 17) The Parliament has introduced a package of amendments to the Electoral Code. Belarusian news. https://tinyurl.com/w87adct8

Borukhina, I. Yu. (2013) Electoral systems in the CIS and EU member states. Political science issues, 1 (9), 172-179. https://www.twirpx.com/file/2818627/

Casanovskaya, Yu.A., Ganitsky, A.G. (2016) National Constitutions in the system of sources of electoral law of the CIS countries. Modern trends in the development of science and technology. Tkacheva E.P., Belgorod, 42-46. https://tinyurl.com/4mhjsaw7 
Central Commission for the Conduct of Elections and Referenda in Turkmenistan (2018) On amendments and additions to the Electoral Code of Turkmenistan. Central Commission for the Conduct of Elections and Referenda in Turkmenistan https://tinyurl.com/bwmyysss

Central Election Commission of Gagauzia (2019, April 10) The Central Electoral Commission of Gagauzia in the legal field of the RepublicMoldova. Central Election Commission of Gagauzia. https://tinyurl.com/k484xvzs

Jeenbekov S. (2019, August 13) Sooronbai Jeenbekov signed a package of election laws. Major changes. Kaktus.media. https://tinyurl.com/2vxk7t34

Kharchenko D. (2019, September 15) The Servant of the People will revise the vetoed Electoral Code. HB.

https://tinyurl.com/uaswfjxz

Maslovskaya, T. (2012) Trends in the evolution of electoral legislation in the CIS countries. ELIB BSU. https://tinyurl.com/vr8a52u4

Potapova, E.A. (2014, July 3) Electoral law in the constitutions of the CIS countries. State and law: theory and practice: materials of the III Intern. scientific conf. (July 2014). House Young Scientist, Chita, 14-15.

https://moluch.ru/conf/law/archive/115/6024/

Press Center Regnum (2018, May 23) The Parliament of Kazakhstan adopted amendments to the election law. Regnum. https://tinyurl.com/du9vbnfd

Press Center Regnum (2019, September 10) Armenian authorities are embarking on global changes to the Election Code. Regnum. https://tinyurl.com/yvkb96sf

Press club in the Sughd region of the Republic of Tajikistan (2019, June 24) A new bill prohibits members of political parties in Tajikistan from joining the Central Election Commission. Sogdiana. https://tinyurl.com/p4unfnjj

Russian Foundation for Free Elections (2019) Draft federal law «Code on Elections and Referenda in the Russian Federation» (Electoral Code of Russia). Russian Foundation for Free Elections. https://tinyurl.com/s89xv3uw Sputnik Azerbaidzan (2018, January 11) Fifty amendments have been introduced to the Electoral Code of Azerbaijan. https://tinyurl.com/smmu4s77

Sputnik Uzbekistan (2019, June 26) The Electoral Code has been approved in Uzbekistan. Sputnik Uzbekistan https://tinyurl.com/n35vyakm 